\title{
Small-fragment restriction endonuclease analysis in epidemiological mapping of group A streptococci
}

\author{
H. MYLVAGANAM*†, B. BJORVATN*, T. HOFSTAD $\dagger$, R. HJETLAND $\dagger$, E. ARNE HOIBY $\ddagger$ \\ and S. E. HOLM§ \\ * Centre for International Health, $\uparrow$ Department of Microbiology and Immunology, The Gade Institute, University of \\ Bergen, $\ddagger$ National Institute of Public Health, Os/o, Norway, and $\S$ Department of Clinical Bacteriology, \\ Umeå University, Umeå, Sweden
}

\begin{abstract}
Summary. The usefulness of small-fragment restriction endonuclease digest analysis (SFREA) of group A streptococcal DNA with EcoRI, as a supplement to the more conventional $\mathrm{T}$ serotyping, was assessed for epidemiological characterisation. One hundred and thirty-five clinical isolates from 1988-1990 were examined. SF-REA provided characteristic fingerprints of all isolates, whereas eight isolates were non-typable by T serotyping. Generally, there was a striking correlation between the results obtained with the two techniques. Furthermore, SFREA reliably classified the eight $\mathrm{T}$-non-typable isolates and occasionally revealed subgroups within the T serotypes. In addition, SF-REA was useful for the clarification of discrepancies between serotyping results from two different reference laboratories. No obvious correlation was observed between the DNA fingerprints and the clinical manifestations of infection or the geographical origin of the group A streptococcal isolates. SF-REA is a valuable supplement to $\mathrm{T}$ typing in epidemiological studies and frequently appears to be a more efficient tool for strain differentiation.
\end{abstract}

\section{Introduction}

Over the last few years the incidence, morbidity and mortality of infections with $\beta$-haemolytic streptococci of Lancefield's group A have increased in Norway, ${ }^{1}$ as well as in several other parts of the world, ${ }^{2-4}$ and in some places there has been a resurgence of rheumatic fever. ${ }^{5-7}$ Serotyping with antisera against the surface proteins $\mathrm{M}$ and $\mathrm{T}$ has been the standard approach in epidemiological studies of such infections.

$\mathbf{M}$ typing is associated with a higher failure rate than $\mathrm{T}$ typing, and the development and maintenance of a suitable bank of $\mathbf{M}$ antisera is cumbersome and expensive, and is now limited to only a few laboratories in the world. Occasional absence of $\mathrm{M}$ protein, altered antigenic determinants only weakly reactive with typespecific antisera, and the emergence of new non-crossreacting serotypes from mutations of typable strains that produce $M$ antigens for which no typing sera are available $^{8}$ make $\mathbf{M}$ typing an even more difficult exercise.

$\mathrm{T}$ typing provides a means of labelling untypable $\mathrm{M}$ strains, but has the disadvantage that a single $T$ antigen may be shared among several $M$ types. Furthermore, the same $M$ antigen may occur in strains with different $\mathrm{T}$ antigens. ${ }^{9}$ The presence or absence of

Received 26 Sept. 1993; accepted 1 Oct. 1993.

*Correspondence should be sent to Dr H. Mylvaganam, Centre for International Health, Haukeland sykehus, N-5021, Norway. the opacity factor (OF) within a $\mathrm{T}$ type bears a predictable relationship to $\mathrm{M}$ types, ${ }^{9}$ so preliminary $\mathrm{T}$ typing followed by screening for $\mathrm{OF}$, with or without subsequent $\mathrm{M}$ typing, has been practised for some time in epidemiological studies. Although serotyping gives valuable information, a proportion of isolates remains untypable even with the most comprehensive set of typing sera; therefore, there is a need for more reliable methods of strain differentiation, especially for epidemiological mapping of strains of group A streptococci of high virulence. ${ }^{10}$ Restriction endonuclease analysis (REA) has a potential for exact epidemiological mapping. With this technique, the extent of genomic similarity can be expressed as the percentage of identical bands in the DNA fingerprints to be compared. REA of group A streptococci, as a potential substitute for $M$ typing, has been reported in the past. ${ }^{11}$ In the present study, we employed smallfragment restriction endonuclease digest analysis (SFREA) for clonal differentiation, to assess its usefulness as a supplement to $T$ and $M$ serotyping and as an independent epidemiological tool.

\section{Materials and methods}

\section{Bacterial isolates and serogrouping}

The study included 135 isolates of group A streptococci obtained from clinical specimens at the Department of Microbiology and Immunology serving 
Table I. Distribution of clinical diagnoses of the 135 group A streptococcal isolates studied

\begin{tabular}{lc} 
Clinical presentation & Number of isolates \\
\hline Pharyngitis & 92 \\
Septicaemia or serious organ involvement & 18 \\
Scarlet fever & 10 \\
Skin infection & 6 \\
No available information & 9 \\
\hline
\end{tabular}

the Bergen area of Norway: 117 were isolated during the period November 1988-May 1989 and 18 in December 1989--January 1990. The patients represented both sexes, different age groups and a clinical spectrum ranging from mild pharyngitis to lethal septicaemia, as shown in table I.

Serogrouping was performed with the Streptokit (bioMérieux, Marcy l'Etoile, France) and the isolates were stored at $-70^{\circ} \mathrm{C}$ in Greave's medium until processed.

\section{Small-fragment restriction endonuclease analysis}

SF-REA of bacterial DNA was performed as described by Bjorvatn et al., ${ }^{12}$ with a few modifications. Briefly, the bacteria were cultured overnight on blood agar plates, harvested with buffer (Triton X-100 0.5\%, $5 \mathrm{~mm}$ EDTA, $10 \mathrm{~mm}$ Tris base, $0.5 \mathrm{M} \mathrm{NaCl}, \mathrm{pH} \mathrm{8.0)}$ and the protoplasts were released with 50 units of mutanolysin (Sigma), constituted with $0.1 \mathrm{M}$ phosphate buffer, $\mathrm{pH} 6 \cdot 2$. The protoplasts were lysed with $50 \mu \mathrm{l}$ of $0 \cdot 2$ M EDTA, pH $8 \cdot 0,30 \mu$ l of sarkosyl (Sigma; $20 \% \mathrm{w} / \mathrm{v}$ in $50 \mathrm{~mm}$ Tris- $\mathrm{HCl}, \mathrm{pH} 8.0$ ) and $200 \mu \mathrm{l}$ of lysis mix (50 mM Tris- $\mathrm{HCl}$, Triton X100 2\% and $10 \mathrm{~mm}$ EDTA, pH 8.0). RNA was treated with RNAase. Extractions with phenol and chloroform removed proteins and lipids. The clear upper aqueous phase was extracted with equal volumes of $2.5 \mathrm{M}$ phosphate buffer ( $2.5 \mathrm{M} \mathrm{K}_{2} \mathrm{PO}_{4}, \mathrm{pH} 8.0$ and phosphoric acid $33 \%$ as $20+1 \mathrm{vol}$ ) and 2-methoxy-ethanol to remove polysaccharides. Ethanol precipitation in the presence of $0.05 \mathrm{mM} \mathrm{NaCl}$ was performed instead of dialysis. DNA concentrations were measured with a spectrophotometer and $25 \mu \mathrm{g}$ were digested with EcoRI in $50-\mu \mathrm{l}$ volumes under conditions recommended by the manufacturer (New England Biolabs, 32 Tozer Road, Beverly, MA, USA). Separation of the resulting DNA fragments was by electrophoresis through a polyacrylamide $4 \%$ gel with TBE buffer (/L: Tris-base $7.236 \mathrm{~g}$, boric acid $3.685 \mathrm{~g}$ and EDTA $0.623 \mathrm{~g}, \mathrm{pH} \mathrm{8.3)}$. A current of $22 \mathrm{~mA}$ and $580 \mathrm{~V}$ was used for a period of $22 \mathrm{~h}$. Polyacrylamide gel was preferred as it provided better resolution of the bands than did agarose gel. The DNA bands were visualised with ultraviolet light and photographed after staining the gel with ethidium bromide. Interpretation of the results was by visual comparison of the individual fingerprints; these comprised 40-50 individual bands that represented fragment sizes between 0.56 and
$4 \cdot 2 \mathrm{~kb}$. The degree of similarity percent was calculated as follows: $\left[2 \times \mathrm{N}_{\mathrm{s}} /\left(\mathrm{N}_{1}+\mathrm{N}_{2}\right)\right] \times 100$, where $\mathrm{N}_{\mathrm{s}}$ is the number of bands shared and $N_{1}$ and $N_{2}$, the number of bands, respectively, in the two prints compared. Identical patterns were considered to represent a single clone and those with $\geqslant 96 \%$ similarity were considered to be recently derived from the same clone.

\section{Serotyping}

All isolates were $\mathrm{T}$ typed and tested for the production of $\mathrm{OF}$ at the National Institute of Public Health (NIPH) in Oslo. M typing was performed on 24 selected isolates which included those from serious infections. T typing was based on agglutination with specific antisera (Chemapol, Kodañská 46, 10010 Praha 10-Visovice, Czechoslovakia). The presence of OF was determined by the method of Maxted and Widowson. ${ }^{13} \mathrm{M}$ antigen was extracted with $0 \cdot 2 \mathrm{M} \mathrm{HCl}$ and precipitated with specific rabbit antisera by a geldiffusion technique.

Independent $\mathrm{T}$ typing of 36 isolates was performed at the University of Umeå. The strains were selected mainly from two categories: (i) isolates with a $\mathrm{T}$ type different from the one suggested by genotyping; and (ii) isolates representing SF-REA subgroups, to seek further serotype differentiation.

\section{Results}

$E c o$ RI provided characteristic and reproducible DNA fingerprints of all 135 isolates. Twenty-four SFREA patterns $(\mathrm{A}-\mathrm{X})$, which differed from each other by more than $4 \%$, were recognised; 11 patterns were represented by one isolate only (table II). No attempt was made to create a pedigree of these 24 patterns.

At NIPH, 127 isolates were serotypable and $11 \mathrm{~T}$ types were identified, three of which had both $\mathrm{OF}+$ and $\mathrm{OF}-$ members. $\mathrm{T}$ typing failed with eight $(6 \%)$ of the 135 isolates. The DNA fingerprints of four of these were identical to those of other isolates tested; two had patterns shared by serotype T12 OF - and one each by $\mathrm{T} 25 \mathrm{OF}+$ and T6 OF - . Each of the remaining four T-non-typable isolates had a unique fingerprint.

The correlation between the 24 SF-REA patterns and the corresponding serotypes is shown in table II. The SF-REA groups D and E, classified as T4 OF + and $\mathrm{T} 4 \mathrm{OF}-$, respectively, showed $90 \%$ similarity. The SF-REA groups $F$ and $G$, though serotypically identical, differed by $>60 \%$ (figure).

At the University of Umeå, 15 of the 36 selected isolates were non-typable; the typing results of the others were consistent with those from NIPH. Ten of the non-typable 15 had been classified as T3, T3/B3264 or T3/13/B3264 OF + at NIPH. SF-REA revealed that these 10 isolates were genetically closely related ( $\geqslant 96 \%$ similarity) to T12 M22. In fact, one of the isolates was re-checked in Umeå and typed as T12 M22. 
Table II. Correlation between serotyping and SF-REA patterns of 135 isolates

\begin{tabular}{|c|c|c|}
\hline Number of isolates & Serotype and opacity reaction & SF-REA \\
\hline 37 & $\mathrm{~T} 1 \mathrm{OF}-$ & $\mathbf{A}$ \\
\hline $15: 2 \dagger$ & $\mathrm{T} 12 \mathrm{OF}-\mathrm{M} 12: \mathrm{T}$ non-typable $\mathrm{OF}-\dagger$ & B \\
\hline $4: 10^{*}$ & $\mathrm{~T} 12 \mathrm{OF}+\mathrm{M} 22: \mathrm{T} 3 / 13 / \mathrm{B} 3264 \mathrm{OF}+*$ & $\mathrm{C}$ \\
\hline 15 & $\mathrm{~T} 4 \mathrm{OF}+\mathrm{M} 4$ & $\mathbf{D}$ \\
\hline 1 & $\mathrm{~T} 4 \mathrm{OF}-$ & $\mathrm{E}$ \\
\hline 12 & $\mathrm{~T} 28 \mathrm{OF}+$ & $\mathrm{F}$ \\
\hline 3 & $\mathrm{~T} 28 \mathrm{OF}+$ & $\mathrm{G}$ \\
\hline $11: 1 \dagger$ & $\mathrm{T} 25 \mathrm{OF}+: \mathrm{T}$ non-typable $\mathrm{OF}+\dagger$ & $\mathrm{H}$ \\
\hline 4 & $\mathrm{~T} 11 \mathrm{OF}+$ & I \\
\hline 3 & $\mathrm{~T} 13 \mathrm{OF}+\mathrm{M} 13$ & $\mathbf{J}$ \\
\hline 2 & $\mathrm{~T} 3 \mathrm{OF}+$ & $\mathbf{K}$ \\
\hline $1: 1 \dagger$ & T6 OF $-: \mathrm{T}$ non-typable $\mathrm{OF}-\dagger$ & $\mathrm{L}$ \\
\hline 2 & T14 Of + & $\mathbf{M}$ \\
\hline 1 & $\mathrm{~T} 3 / 13 / \mathrm{B} 3264 \mathrm{OF}+$ & $\mathbf{N}$ \\
\hline 1 & $\mathrm{~T} 3 / 13 / \mathrm{B} 3264 \mathrm{OF}+$ & $\mathrm{O}$ \\
\hline 1 & $\mathrm{~T} 3 / \mathrm{B} 3264 \mathrm{OF}+$ & $\mathrm{P}$ \\
\hline 1 & T3 OF - & Q \\
\hline 1 & T3/B3264 OF - & $\mathbf{R}$ \\
\hline 1 & $\mathrm{~T}$ non-typable $\mathrm{OF}-$ & $\mathbf{S}$ \\
\hline 1 & T non-typable OF - & $\mathrm{T}$ \\
\hline 1 & T non-typable OF - & $\mathrm{U}$ \\
\hline 1 & $\mathrm{~T}$ non-typable $\mathrm{OF}+$ & V \\
\hline 1 & $\mathrm{~T} 2 \mathrm{OF}+$ & W \\
\hline 1 & T8 Imp 19 OF - & $\mathrm{X}$ \\
\hline
\end{tabular}

*These isolates were typed as T3, T3/B3264 or T3/13/B3264 OF+ at NIPH and classified as T-non-typable in Umeå; when one isolate was re-checked in the same laboratory, it was found to be $\mathrm{T} 12 \mathrm{OF}+\mathrm{M} 22$.

$\dagger$ These non-typable strains were characterised and grouped by REA.

T $28 \mathrm{OF}+$

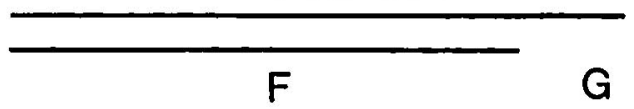

T 11 OF+

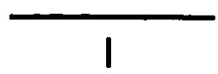

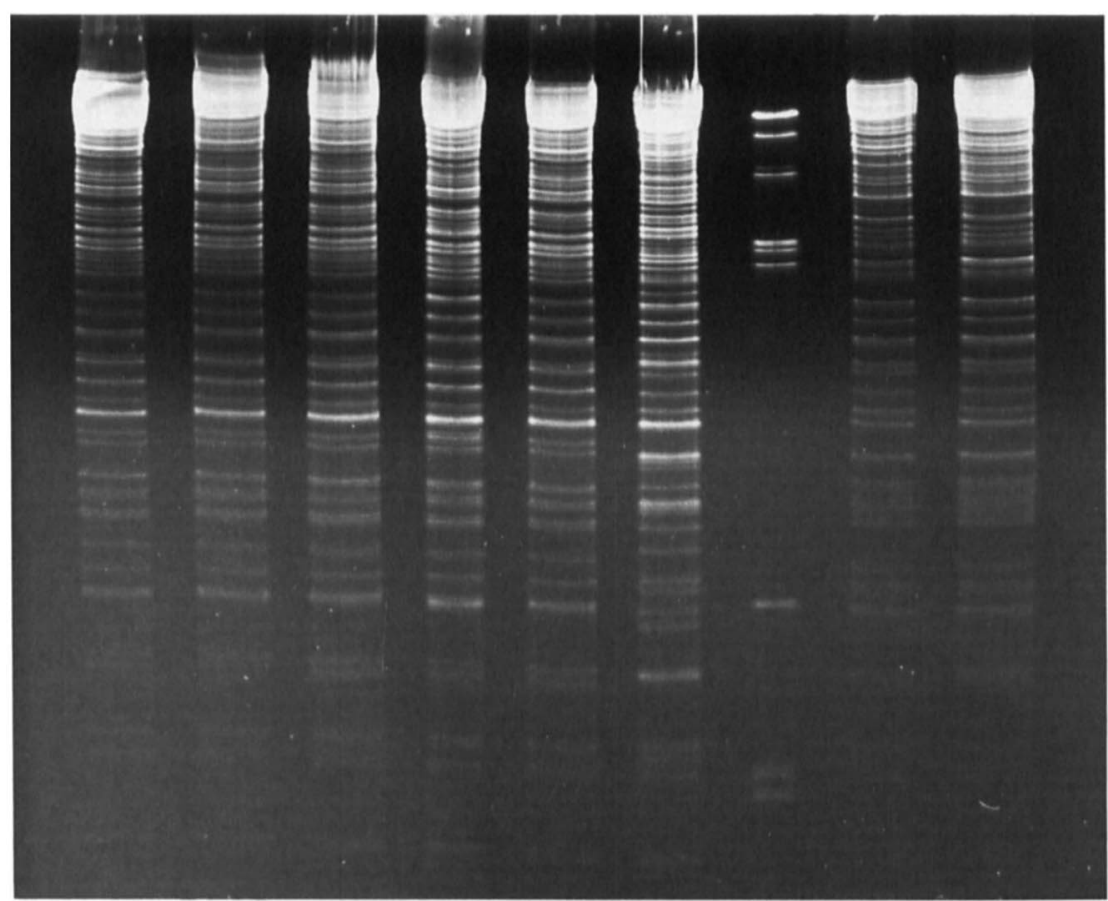

1

23

4

56

7

89

Figure. A representative gel showing the DNA patterns of six T28 OF + isolates (lanes 1-6) and two T11 OF + isolates (lanes 8-9). The pattern of lane 6 (SF-REA group G) clearly deviates from the other T28 OF + representatives (group F), whereas the two T11 OF + isolates appear genetically identical. (Lane 7 represents a fragment size marker.) 
Table III. Correlation between M typing, T typing and SFREA

\begin{tabular}{|c|c|c|c|}
\hline Number of isolates & M type & T type & SF-REA \\
\hline 11 & M1 & T1 OF - & A \\
\hline 1 & Not $\left.\mathrm{M}_{1}\right\}$ & & \\
\hline 4 & M12 & T12 OF - & B \\
\hline 1 & Not M12 & & \\
\hline 4 & M22 & $\mathrm{T} 12 \mathrm{OF}+$ & $\mathrm{C}$ \\
\hline 3 & M13 & T13 OF + & $\mathbf{J}$ \\
\hline 1 & M4 & $\mathrm{T} 4 \mathrm{OF}+$ & $\mathrm{D}$ \\
\hline
\end{tabular}

Members of the T3/13/B3264 complex reacted with some, but not all of the antibodies that characterised the complete complex. In addition to the 10 genotypically homogeneous members mentioned above, another 10 isolates belonged to this complex and REA characterisation of these isolates revealed seven distinct genomic patterns (table II): three were T13, $\mathrm{OF}+\mathrm{M} 13$ (SF-REA group J); two were T3 OF + (SF-REA group $\mathrm{K}$ ); two were T3/13/B3264 OF + (SF-REA groups $\mathrm{N}$ and O); one was T3/B3264 OF + (SF-REA group $\mathrm{P}$ ); one was T3 OF - (SF-REA group $\mathrm{Q}$ ); and one was T3/B3264 OF - (SF-REA group R).

The results of $M$ typing and the correlation with $T$ typing and fingerprint patterns are shown in table III. The $\mathrm{M}$ antigen may or may not occur in isolates that are completely homogeneous by $\mathrm{T}$ typing as well as by REA.

The SF-REA results gave no indication of specific clonal patterns associated with particular clinical manifestations, geographical origin, age or sex of the patients involved.

\section{Discussion}

Generally, there was a striking correlation between the typing results obtained with conventional $\mathrm{T}$ typing combined with the serum opacity reaction and SFREA and once the DNA fingerprint pattern was defined, it was possible to predict in most instances the corresponding serotype. Furthermore, at NIPH Ttyping failed with eight $(6 \%)$ of the isolates, all of which were easily characterised by SF-REA; four of these eight were shown to be genetically identical to Ttypable isolates. Further problems associated with conventional serotyping are illustrated by the 10 isolates allocated at NIPH to the T3/13/B3264 complex, but recorded as T-non-typable in Umeå. These 10 isolates were found by SF-REA to have close genetic similarity to the T12 M22 group. This result was supported in Umeå upon re-checking one of the isolates in question. Such discrepancies in T typing have been reported and explained in the past $;{ }^{9} \mathrm{REA}$ is useful under these circumstances.

The strains of SF-REA groups D and E could represent closely related clones, with loss of expression of the genes encoding the OF factor, ${ }^{14}$ or defective transcription or translation in group E. On the other hand, the absence of M1 and M12, respectively, within single SF-REA clones may indicate a modified phenotypic expression without major changes in the genome. It is well known that group A streptococci occasionally produce $\mathrm{M}$-negative variants ${ }^{15}$ and this makes genotypic differentiation by techniques such as REA an attractive alternative to typing methods based on surface antigens. The advantage of genotyping for exact strain differentiation is further illustrated by the recognition by SF-REA of two distinct groups among the 15 apparently homogeneous T28 OF + isolates. Each of the two groups had an almost complete internal homogeneity, but differed from each other by $>60 \%$. M typing in this instance would have been informative, but was not possible due to the unavailability of corresponding antisera. However, it should be realised that some phenotypic characteristics are directly linked to virulence, and hence refined phenotypic methods may still be an important additional tool for particular epidemiological purposes.

In M1 strains, a characteristic "invasive" REA profile was identified recently, based on the specific organisation of the high mol. wt DNA fragments. ${ }^{16}$ Although the present study, in examining a much smaller range of fragment size, did not reveal specific DNA bands associated with serious disease, a more comprehensive analysis of possible fragment polymorphism in different size ranges is indicated. Even highly virulent strains may cause disease only occasionally, hence strains collected from cases and close contacts of serious streptococcal disease should be compared with carrier strains from a non-endemic population. Such studies have been presented recently with other genotypic methods. ${ }^{17,18}$

REA is not the only genotypically based technique available for strain differentiation. Promising results were obtained recently with DNA probes for the hypervariable region of the emm gene of 10 different $M$ types, ${ }^{19}$ although sequencing the $\mathrm{N}$-terminal regions of emm genes of more than 80 different $\mathrm{M}$ types renders it very time consuming. The presence of variants within the $\mathrm{M}$ types,${ }^{20}$ occasional possession of multiple $\mathrm{M}$ antigens in the same strain, ${ }^{10}$ and loss of $\mathrm{M}$ antigen, ${ }^{15,21}$ present further problems in this approach.

Ribotyping of group A streptococci has not been shown to be superior to REA for strain differentiation. ${ }^{22}$

Multilocus enzyme electrophoresis is an elegant tool for epidemiological mapping, although identical electromorphs might be sequentially heterogeneous, particularly at the level of genetic sequence, owing to silent substitutions. Post-translational modification is another potential source of error. ${ }^{23}$ When compared with serotyping, multilocus enzyme electrophoresis has been shown to be more useful for epidemiological mapping and diagnostic differentiation of group $\mathrm{A}$ streptococci, although results did not fully match. ${ }^{20}$

REA is exact and highly reproducible, but labourintensive and technically demanding. However, automated DNA extractors which yield highly purified 
DNA, and an awareness of common technical pitfalls will undoubtedly increase the reliability and acceptability of this method, which provides information on the overall organisation of the chromosomal and, possibly, also of extrachromosomal DNA; this could be useful in epidemiological analyses. In this study SFREA had a resolving power which exceeded that of serological techniques.

\section{References}

1. Martin PR, Høiby EA. Streptococcal serogroup A epidemic in Norway 1987-1988. Scand J Infect Dis 1990; 22: 421-429.

2. Ispahani P, Donald FE, Aveline AJD. Streptococcus pyogenes bacteraemia: an old enemy subdued, but not defeated. $J$ Infect 1988; 16: 37-46.

3. Smyth EG, Weinbren MJ. Severe group A streptococcal infection. Lancet 1988; 2: 452. (Letter).

4. Stollerman GH. Changing group A streptococci. The reappearance of streptococcal 'toxic shock'. Arch Intern Med 1988; 148: $1268-1270$.

5. Hosier DM, Craenen JM, Teske DW, Wheller JJ. Resurgence of acute rheumatic fever. Am J Dis Child 1987; 141: 730-733.

6. Kaplan EL. The resurgence of group A streptococcal infections and their sequelae. Eur J Clin Microbiol Infect Dis 1991; 10: $55-57$.

7. Veasy LG, Weidmeier SE, Orsmond GS et al. Resurgence of acute rheumatic fever in the intermountain area of the United States. $N$ Engl J Med 1987; 316: 421-427.

8. Fox EN. M Proteins of group A streptococci. Bacteriol Rev $1974 ; 38: 57-86$

9. Johnson DR, Kaplan EL. A review of the correlation of Tagglutination patterns and $\mathrm{M}$-protein typing and opacity factor production in the identification of group A streptococci. J Med Microbiol 1993; 38: 311-315.

10. Schwartz B, Facklam RR, Breiman RF. Changing epidemiology of group A streptococcal infection in the USA. Lancet $1990 ; 336$ : 1167-1171.

11. Cleary PP, Kaplan EL, Livdahl C, Skjold S. DNA fingerprints of Streptococcus pyogenes are M type specific. $J$ Infect Dis 1988; 158: $1317-1323$

12. Bjorvatn B, Lund V, Kristiansen B-E, Korsnes L, Spanne O, Lindqvist B. Applications of restriction endonuclease fingerprinting of chromosomal DNA of Neisseria meningitidis. J Clin Microbiol 1984; 19: 763-765.

13. Maxted WR, Widowson JP. The protein antigens of group A
We conclude that, for epidemiological studies that require reliable and exact differentiation between clinical isolates of group A streptococci, there is a need for conventional serological typing to be supplemented. REA is a useful technique for this purpose.

We thank Vibecke Asphaug for excellent technical assistance, Gro Lermark for serotyping all our isolates and Carin Olofsson for re-typing some isolates. streptococci. In: Wannamaker LW, Matsen JM (eds) Streptococci and streptococcal diseases. New York, Academic Press. 1972: 251-266.

14. Cleary PP. Genetic separation of serum opacity factor from $M$ protein of group A streptococci. Infect Immun 1978; 22: 171-175.

15. Fischetti VA. Streptococcal M protein: molecular design and biological behavior. Clin Microbiol Rev 1989; 2: 285-314.

16. Cleary PP, Kaplan EL, Handley JP et al. Clonal basis for resurgence of serious Streptococcus pyogenes disease in the 1980s. Lancet 1992; 339: 518-521.

17. Holm SE, Norrby A, Bergholm A-M, Norgren M. Aspects of pathogenesis of serious group A streptococcal infections in Sweden, 1988-1989. J Infect Dis 1992; 166: 31-37.

18. Norgren M, Norrby A, Holm SE. Genetic diversity in T1M1 group A streptococci in relation to clinical outcome of infection. J Infect Dis 1992; 166: 1014-1020.

19. Kaufhold A, Podbielski A, Johnson DR, Kaplan EL, Lütticken R. M protein gene typing of Streptococcus pyogenes by nonradioactively labelled oligonucleotide probes. $J$ Clin Microbiol 1992; 30: 2391-2397.

20. Musser JM, Gray BM, Schliervert PM, Pichichero ME. Streptococcus pyogenes pharyngitis: characterization of strains by multilocus enzyme genotype, $M$ and $T$ protein serotype, and pyrogenic exotoxin gene probing. $J$ Clin Microbiol 1992; 30: 600-603.

21. Spanier JG, Jones SJC, Cleary P. Small DNA deletions creating avirulence of Streptococcus pyogenes. Science 1984; 225: 935-938.

22. Bingen E, Denamur E, Lambert-Zechovsky N, Braimi N, El Lakany $\mathrm{M}$, Elion J. DNA restriction fragment length polymorphism differentiates recurrence from relapse in treatment failures of Streptococcus pyogenes pharyngitis. $J$ Med Microbiol 1992; 37: 162-164.

23. Selander RK, Caugant DA, Ochman H, Musser JE, Gilmour MN, Wittam TS. Methods of multilocus enzyme electrophoresis for bacterial population genetics and systematics. Appl Environ Microbiol 1986; 51: 873-884. 